\title{
David A. Volgas and Yves Harder: AOTRAUMA manual of soft- tissue management in orthopaedic trauma
}

\author{
Thieme Verlag, New York, Stuttgart, Delhi, Rio, Hardcover, 336 pp., € 139.99, ISBN: \\ 978-3-13-166371-9
}

Pierre Kehr ${ }^{1}$

Received: 15 March 2016/Accepted: 25 April 2016/Published online: 10 June 2016

(C) Springer-Verlag France 2016

This book stresses the importance of soft tissues in the assumption of responsibility of the fractures and not only within the framework of the open fractures.

The illustration is very rich with many drawings and photographs facilitating the comprehension of the techniques and is reinforced by the presence of explanatory videos on the website. Clinical cases at the end of the book make it possible to put into practice and to stress the importance of a total treatment of the fractures and surrounding tissues.

The first part treats general information on vascularization, the cicatrization of soft tissues, but also of the various types of lesions like the wounds by bullets or blast.
Classifications are also clarified, just as the organization of the trauma centre.

The principles of debridement are described as well as the various techniques of cover of simplest to most complicated. The large traditional scraps are also described and put in situation with their advantages and disadvantages.

This very didactic book is addressed in first to the young surgeons but also to young people who are less familiar with the assumption of responsibility of heavy traumatology.

Compliance with ethical standards

Conflict of interest None.

Pierre Kehr

pierre.kehr@gmail.com

1 Strasbourg, France 